\title{
PENGEMBANGAN KOMPETENSI KEBAHASAAN DALAM MENULIS TEKS CERPEN SEJARAH DI MAN 7 JOMBANG
}

\section{Rani Jayanti*, Yesy Diah Rosita}

Pendidikan Bahasa dan Sastra Indonesia, Fakultas Keguruan dan Ilmu Pendidikan, Universitas Islam Majapahit Jl. Raya Jabon KM.0.7 Mojokerto, Indonesia

*Corresponding author: ranijayanti_12@yahoo.com

\section{INFORMASI ARTIKEL}

Sejarah Artikel

Diterima: $11 / 10 / 2019$

Direvisi: $23 / 11 / 2019$

Diterima: 25/11/2019

Tersedia Daring: 29/2019

Kata Kunci

Bahan ajar

Kearifan Lokal

MAN 7 Jombang

\section{ABSTRAK}

Tujuan dalam penelitian ini untuk mengetahui kompetensi kebahasaan dalam menulis teks cerpen sejarah siswa. Alasan utama peneliti mengadakan riset untuk mencari tahu tentang hal yang mempengaruhi meningkatnya kebahasaan setiap siswa terutama dalam menyusun teks cerpen sejarah yang berbasis kearifan lokal. Penelitian ini menggunakan metode penelitian dan pengembangan. Hasil penelitian yaitu hasil uji coba pre-test dan post-test peserta didik MAN 7 Jombang mengalami perbedaan, dari nilai pre-test pada tabel 1 lebih rendah dengan rata-rata 79. Sedangkan, hasil dari nilai post-test lebih tinggi dengan rata-rata 84,13. Jadi, ada ketidaksamaan yang penting dalam penggunan pengembangan bahan ajar berupa modul. Bahan ajar modul dapat dinyatakan mampu meningkatkan hasil belajar dan pemahaman siswa secara efektif.

\section{ABSTRACT}

The purpose of this study is to determine the students' language competence in writing short history texts. The researchers conducted this research to mainly find out about things that affect the improvement of the linguistic competence of each student, especially when composing short history texts based on the local wisdom. This research used research and development methods. The results of the study are the those of the pre-test and post-test trials of MAN 7 Jombang students. The pre-test scores in table 1 are lower with an average of 79. Meanwhile, the results of the post-test scores are higher with an average an average of 84.13. Therefore, it can be assumed that there is an important inequality in the use of developing teaching materials in the form of modules. Module teaching materials are proven to be able to improve students' learning outcomes and understanding.

Copyright@2019, Rani Jayanti, Yesy Diah Rosita This is an open access article under the CC-BY-3.0 license

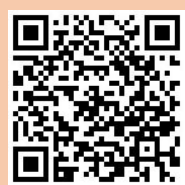

\section{PENDAHULUAN}

Perkembangan zaman menuntut penyesuaian kurikulum pendidikan yang berorientasi kepada perkembangan zaman (Ranem, Mulawarman, \& Sulistyowati, 2018). Bahasa banyak memiliki keunikan, karena bahasa merupakan wujud suatu budaya. Selain itu, bahasa juga menjadi bayangan suatu budaya dalam kelompok yang digunakan untuk berkomunikasi. Bahasa yang baik adalah bahasa yang menggunakan ragam bahasa yang tepat sesuai dengan situasi dan kondisi pemakainya, sedangkan bahasa yang benar adalah bahasa yang mengikuti kaidah yang dibakukan mencakup ejaan, tanda baca, kosakata, dan tata bahasa (Wardarita, 2010). 
Bahasa digunakan sebagai alat untuk berkomunikasi sehari-hari, baik berupa bahasa lisan maupun bahasa tulis. Kegiatan berbahasa yang dianggap sulit adalah menulis. Pembelajaran menulis masih sering menggunakan metode pembelajaran konvensional, dalam pembelajaran menulis biasanya guru cenderung kurang kreatif dan inovatif dalam mengarahkan siswa saat merangkai kata (Amalia \& Doyin, 2015). Salah satu kegiatan berbahasa menulis yang digunakan dalam penelitian dan pengembangan ini adalah berupa cerpen sejarah. Cerpen sejarah atau kejadian masa lalu, baik itu yang dialami diri sendiri maupun orang lain, banyak memberikan informasi penting sebagai pelajaran berharga (Komalasari, 2019).

Saat observasi, peneliti melihat bahwa saat kegiatan pembelajaran siswa masih kesulitan melakukan praktek menulis. Siswa terlihat tidak semangat ketika proses pembelajaran. Siswa hanya mendengarkan ketika guru menerangkan, siswa juga tidak merespon balik apa yang disampaikan oleh guru. Pemilihan bahan ajar dan metode yang menarik dan sesuai diharapkan siswa dapat mengalami peningkatan kompetensi kebahasaan (Listini \& Saraswati, 2017). Oleh karena itu, perlu ditemukan solusi untuk peningkatan dalam pembelajaran menulis teks cerpen sejarah.

Budaya adalah nilai, prinsip yang dapat diyakini kebenarannya dalam suatu masyarakat penutur suatu bahasa, dan dapat menjadi panduan dalam berinteraksi dan berkomunikasi (Achmad, 2012). Cerpen adalah wujud imajinasi dari seorang berupa fiktif. Cerpen dapat diartikan cerita pendek yang mana dapat berupa cerita atau narasi (bukan analisa argumentatif) yang tidak nyata serta tidak benar-benar terjadi tetapi bisa terjadi kapan saja dan dimana saja) serta sangat pendek (Maiza, Abdurahman, \& Zulfikarni, 2018). Oleh karena itu, cerita fiktif yang pendek berdasarkan realitas tersebut hanya mengandung satu kejadian untuk satu efek bagi pembaca.

Pembelajaran adalah suatu proses dimana lingkungan seseorang secara disengaja dikelola untuk memungkinkan ia turut serta dalam tingkah laku tertentu (Setiawati, 2016). Pembelajaran merupakan tercapainya suatu perilaku atau kompetensi pada siswa setelah mengikuti kegiatan pembelajaran. Upaya dalam merumuskan tujuan pembelajaran sangat bermanfaat bagi guru yang memudahkan mengkomunikasikan maksud kegiatan belajar mengajar, memudahkan guru dalam menyusun bahan ajar, serta memudahkan guru menyusun evaluasi dalam proses pembelajaran (Devi, 2018).

Peningkatan kebahasaan dalam pembelajaran bahasa Indonesia dapat diartikan berbeda-beda oleh setiap individu. Menurut Freire (2008) proses belajar dan mengajar siswa dapat ditambahkan materi tentang kearifan lokal yang mana dapat menjadikan siswa dalam pengetahuan yang nyata sesuai dengan apa yang mereka lakukan setiap hari di lingkungannya.

Suatu komunitas dapat dikatakan sebuah kelompok yang mana di dalamnya mempunyai nilai luhur yang asli belum berubah yang digunakan sebagai dasar untuk mengatur suatu kehidupan di suatu kelompok tersebut biasanya disebut kearifan lokal (Haryonik \& Bhakti, 2018). Peningkatan kebahasan siswa berbasis kearifan lokal adalah salah satu pembelajaran bahasa Indonesia berdasarkan K13 yang bertujuan untuk pengembangan aspek fungsional bahasa yaitu peningkatan kompetensi bahasa.

Dewasa ini banyak sekali cara yang digunakan untuk peningkatan belajar siswa salah satunya dengan membuat bahan ajar yang inovatif yang mudah dipahami oleh siswa, pengembangan bahan ajar ini diharapkan dapat meningkatkan kompetensi kebahasaan dalam menulis teks cerpen sejarah di MAN 7 Jombang yang selama ini dianggap sulit oleh siswa karena minimnya kosakata yang mereka kuasai. Pengembangan bahan ajar berupa modul yang berbasis kearifan lokal ini dapat mendukung siswa dalam proses menyusun teks cerita sejarah dan membantu siswa dalam menyelesaikan minimnya cara dalam menulis pemula. 
Saat melakukan proses pembelajaran di dalam kelas dengan indikator menulis cerita pendek sejarah banyak permasalahan yang dihadapi oleh siswa yaitu pertama, ketika diperintah untuk mengembangkan sebuah cerita pendek terutama cerita pendek sejarah maka siswa akan mengalami kesulitan dalam menentukan ide pokok atau gagasan utama. Kedua, kosakata yang dimiliki siswa dianggap masih belum mempenuhi atau bisa dikatakan kurang saat proses menulis teks cerita sejarah yang berbasis kearipfan lokal. Oleh karena itu, ini dapat mempengaruhi saat menulis dan banyak muncul kata tidak baku dalam menulis._Ketiga, teknik yang seharusnya sudah dikuasai oleh pendidik juga belum diterapkan pada siswa saat menulis cerita sejarah berbasis kearifan lokal, dan ini mempengaruhi saat siswa menulis dan mengalami kendala pada proses pengembangan ide cerita (Mastini, Suwandi, \& Sumarwati, 2016).

Pengembangan bahan ajar ini dianggap penting karena peneliti dapat melihat bahan ajar ini mampu memotivasi siswa dalam menulis teks cerita sejarah dengan kebahasaan yang sudah terstruktur di dalam modul. Terutama dalam menulis teks cerita sejarah yang berbasis kearifan lokal yang dihubungkan dengan kearifan lokal yang ada di lingkungan sekitar tempat tinggal siswa yang mempunyai nilai sejarah. Sampai saat ini yang masih dapat dinikmati oleh banyak masyarakat tetapi permasalahan terkini selain siswa dapat menulis sesuai kompetensi kebahasaan siswa juga dapat menyumbang cerita pendek sejarah yang nantinya bisa digunakan sebagai referensi asal mula kearifan lokal yang ada disekitar wilayah mereka.

Tujuan penelitian dan pengembangan ini untuk peningkatan kompetensi kebahasaan dalam menulis teks cerpen sejarah melalui pengembangan bahan ajar berupa modul pendamping buku paket bahasa Indonesia kelas XII berbasis kearifan lokal (cerpen) yang dianggap sebagai solusi tepat. Penelitian dan pengembangan dilakukan agar dapat memahami meningkatnya prestasi belajar siswa. Untuk mendukung penelitian dan pengembangan ini, penelitian yang berjudul Pengembangan Modul Berbasis Quantum Learning Tema Ekosistem untuk Kelas V Sekolah Dasar dilakukan oleh (Sasmita \& Fajriyah, 2018). Dari penelitian tersebut dihasilkan, produk modul tematik yang dikembangkan dan dapat digunakan sebagai penunjang bahan ajar siswa kelas V SDN Lamper Tengah 02 Semarang. Data kelayakan tersebut didapat dari validasi materi tahap 1 dan validasi materi tahap 2. Penelitian lain yang dengan judul Pengembangan Media Modul Interaktif pada Materi jurnal Khusus Kelas X Akuntansi di SMK Negeri Mojoagung yang dilakukan oleh (Wahjudi, 2016). Dari penelitian tersebut dihasilkan, kelayakan media pembelajaran modul interaktif yang dikembangkan berdasarkan penilaian ahli materi, ahli media, serta respon siswa menyatakan layak digunakan sebagai media pembelajaran akuntansi di SMK Negeri Mojoagung pada materi jurnal khusus.

Hasil penelitian Sukistiono (2017) menunjukkan pengembangan bahan ajar dari buku pelajaran Bahasa Indonesia terhadap siswa dikelas IX melalui pendekatan berbasis teks dengan metode cerpen-gram. Sedangkan, penelitian Sartini (2016) tentang tahapan aplikasi yang pengembangannya dilakukan oleh Borg \& Gall serta ada 10 (sepuluh) tahapan. Pengaruh penelitian yang diberikan oleh validator media dan materi menganggap bahan ajar yang dihasilkan dapat memadai dengan sangat apik dan berhasil dalam peningkatan kedisplinan dan prestasi pembelajaran siswa yang bagus. Fachrudin (2016) menemukan proses belajar mengajar di kelas dapat memakai bahan ajar seperti modul memberikan pengaruh positif yang mana peningkatan pestasi pembelajaran kognitif peserta didik.

\section{METODE}

Model pengkajian yang digunakan adalah pengkajian Research and Development (R\&D) dengan memakai bentuk penelitian dan pengembangan menurut (Borg \& Gall, 1989). Langkah-langkah penelitian dan pengembangan sebagaimana berikut: 
1. Potensi dan masalah; peneliti melakukan research terhadap objek yang akan diteliti untuk mengetahui problem yang ada di dalamnya.

2. Pengumpulan data; peneliti mengumpulkan beberapa data yang ada di dalam objek penelitian dan mengelompokkan sesuai jenis data yang sudah didapatkan.

3. Desain produk; peneliti mendesain produk penelitian dan pengembangan yang akan digunakan di dalam penelitian.

4. Validasi produk; validasi produk dilakukan agar produk sesuai dengan materi yang disampaikan.

5. Revisi produk; revisi produk bertujuan untuk menyempurnakan materi yang ada di dalamnya, serta menyempurnakan desain yang sesuai dengan pembelajran.

6. Uji coba produk; dilakukan untuk mengetahui apakah produk tersebut layak digunakan atau tidak dalam kegiatan pembelajaran di dalam kelas.

7. Produksi masal; dilakukan agar responden dapat mengunakan produk tersebut dengan baik dan maksimal.

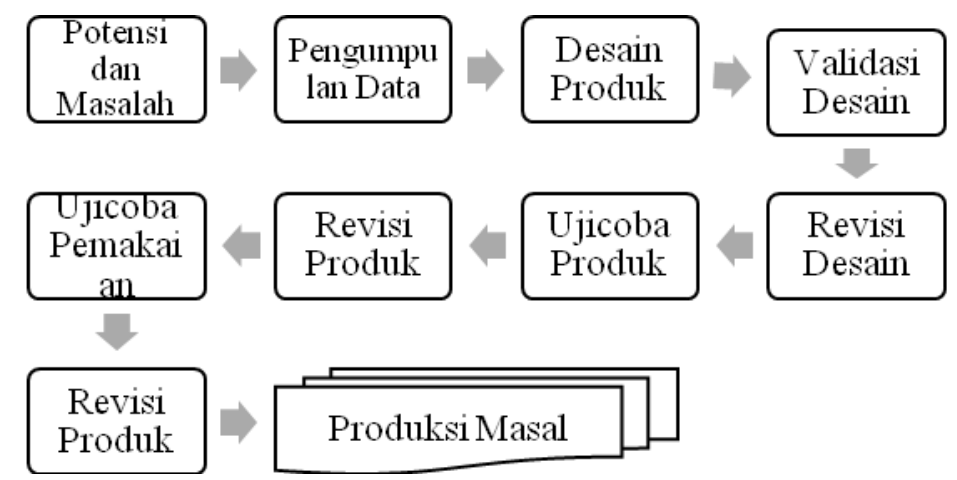

\section{Gambar 1. Model penelitian dan Pengembangan menurut Borg\&Gall}

Sumber data didapat dari penilaian berupa angket untuk siswa, validator ahli media, validator ahli materi, dan validator guru pengampu mata pelajaran bahasa Indonesia. Siswa diberikan tes tulis untuk mengetahui peningkatan hasil belajar siswa. Salain angket dan tes tulis, terdapat wawancara yang diberikan kepada validator guru pengampu mata pelajaran bahasa Indonesia.

Data yang digunakan dalam penelitian dan pengembangan ini berupa data kuantitatif dan kualitatif. Selain itu, penelitian ini diuji coba menggunakan eksperimen before-after, yang mana eksperimen dapat dikerjakan untuk aturan pelaksanaan bentuk objek sebelum dan setelah menggunakan bahan ajar berupa modul. Data uji coba dikumpulkan melalui angket dan tes berupa pretest (tes awal sebelum menggunakan produk) dan postest (tes setelah menggunakan produk) untuk mengetahui perbandingan hasil belajar siswa. Dalam menghitung tingkat perbandingan tersebut, digunakan rumus $t$-test dengan tingkat kemaknaan $0,5 \%$. Adapun hasil analisis data menggunakan rumus Mean (rata-rata) pretest dan postest, setelah itu digunakan rumus $t$-test untuk memperkuat data penelitian. Teknik analisis data yang digunakan adalah dependent sample test. Oleh karena itu, berikut rumus dan perhitungan menggunakan tingkat kemaknaan $0,5 \%$;

$$
t=\frac{\mathrm{D}}{\sqrt{\frac{\mathrm{d}^{2}}{\mathrm{~N}(\mathrm{~N}-1)}}}
$$




\section{Keterangan: \\ T : Uji-t \\ D : Diferrent (X2-X1) \\ $\mathrm{N}$ : Jumlah Sampel}

\section{HASIL DAN PEMBAHASAN}

\section{Hasil}

Setelah menentukan materi yang akan dikembangkan, dilanjutkan proses desain untuk memproduksi modul pembelajaran dengan menggunakan langkah-langkah menyusun konsep produk, mengumpulkan bahan-bahan, dan membuat produk dengan memasukkan bahanbahan yang dikumpulkan dalam modul pembelajaran. Berikut ini tampilan cover produk pada modul pembelajaran kebahasaan dalam menulis teks cerpen sejarah;

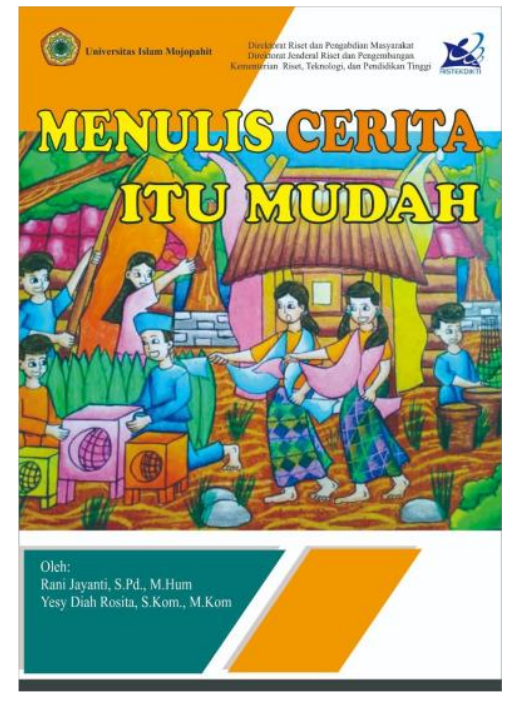

Gambar 2. Tampilan cover depan modul pembelajaran kebahasaan dalam menulis teks cerpen sejarah.

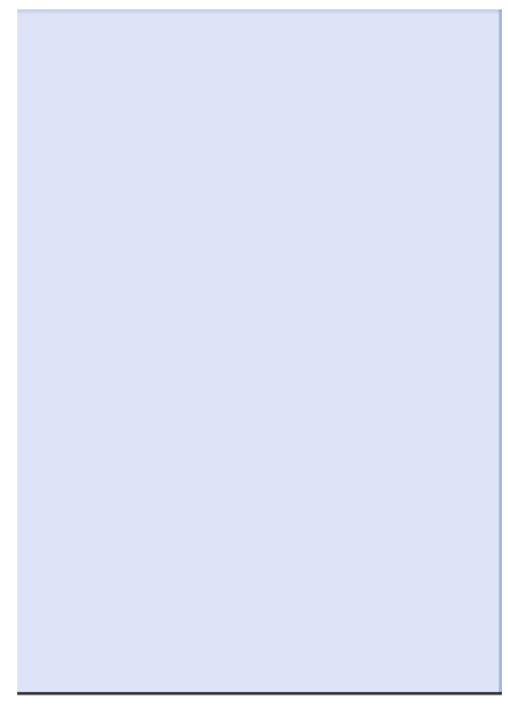

Gambar 3. Tampilan cover belakang modul pembelajaran kebahasaan dalam menulis teks cerpen sejarah.

Penggunaan teknik analisis agar dapat mengetahui ada atau tidak adanya akibat yang terjadi dalam objek penelitian. Dalam menganalisis data, peneliti melakukan langkah-langkah sebagai berikut.

\section{Langkah 1. Menentukan $\mathrm{Ho}$ dan $\mathrm{Ha}$ dalam Bentuk Kalimat.}

Ho : Tidak terdapat perbedaan signifikan terhadap peningkatan hasil belajar siswa kelas XII- IPS MAN 7 Jombang sebelum dan setelah menggunakan bahan ajar berupa modul.

Ha : Terdapat perbedaan siginifikan terhadap peningkatan hasil belajar siswa kelas XII-IPS MAN 7 Jombang sebelum dan sesudah menggunakan bahan ajar berupa modul.

\section{Langkah 2. Menentukan $\mathrm{Ha}$ dan $\mathrm{Ho}$ dalam Bentuk Statistik}

$\mathrm{Ha}: \mu_{\alpha} \neq \mu$

Ho : $\mu_{\alpha}=\mu_{\text {b }}$ 


\section{Langkah 3. Menentukan Normalitas Sebaran Data}

Tabel 1

Hasil Nilai Ujicoba Pre-Test dan Post-Test Serta Normalitas Sebaran Data

\begin{tabular}{cccccc}
\hline NO & Nama & $\begin{array}{c}\text { Pretest } \\
(\mathbf{x})\end{array}$ & $\begin{array}{c}\text { Posttes } \\
(\mathbf{y})\end{array}$ & $\begin{array}{c}\text { GAIN }(\mathbf{d}) \\
(\mathbf{y}-\mathbf{x})\end{array}$ & $\mathbf{d}^{\mathbf{2}}$ \\
\hline 1 & $\mathrm{X} 1$ & 80 & 85 & 5 & 25 \\
\hline 2 & $\mathrm{X} 2$ & 77 & 83 & 6 & 36 \\
\hline 3 & $\mathrm{X} 3$ & 78 & 83 & 5 & 25 \\
\hline 4 & $\mathrm{X} 4$ & 82 & 86 & 4 & 16 \\
\hline 5 & $\mathrm{X} 5$ & 80 & 86 & 6 & 36 \\
\hline 6 & $\mathrm{X} 6$ & 77 & 85 & 8 & 64 \\
\hline 7 & $\mathrm{X} 7$ & 78 & 88 & 10 & 100 \\
\hline 8 & $\mathrm{X} 8$ & 80 & 85 & 5 & 25 \\
\hline 9 & $\mathrm{X} 9$ & 78 & 83 & 5 & 25 \\
\hline 10 & $\mathrm{X} 10$ & 76 & 80 & 4 & 16 \\
\hline 11 & $\mathrm{X} 11$ & 78 & 86 & 8 & 64 \\
\hline 12 & $\mathrm{X} 12$ & 82 & 88 & 6 & 36 \\
\hline 13 & $\mathrm{X} 13$ & 80 & 84 & 4 & 16 \\
\hline 14 & $\mathrm{X} 14$ & 80 & 83 & 3 & 9 \\
\hline 15 & $\mathrm{X} 15$ & 78 & 82 & 4 & 16 \\
\hline 16 & $\mathrm{X} 17$ & 76 & 86 & 10 & 100 \\
\hline 17 & $\mathrm{X} 18$ & 82 & 86 & 4 & 16 \\
\hline 18 & $\mathrm{X} 19$ & 80 & 84 & 4 & 16 \\
\hline 19 & $\mathrm{X} 20$ & 76 & 86 & 10 & 100 \\
\hline 20 & Anggun A.S & 75 & 84 & 9 & 81 \\
\hline & Jumlah & $\mathbf{1 5 7 5}$ & $\mathbf{1 6 9 3}$ & $\mathbf{1 2 0}$ & $\mathbf{8 2 2}$ \\
\hline & Rata-Rata & $\mathbf{7 8 , 7 5}$ & $\mathbf{8 4 , 6 5}$ & $\mathbf{6}$ & $\mathbf{4 1 , 1}$ \\
\hline & & & & &
\end{tabular}

Keterangan:

$$
M d=\frac{\sum d}{n}=\frac{120}{20}=6
$$

Md : rata-rata dari gain antara Pre-tes dan Post-test

d : gain (selisih) skor pre test terhadap post test setiap subjek

$\mathrm{n} \quad$ : jumlah subjek

\section{Langkah 4. Menghitung Rata-Rata}

Menghitung tes rata-rata menggunakan rumus di bawah ini

$$
\begin{aligned}
& t=\frac{M d}{\sqrt{\frac{\sum d^{2}-\frac{(\Sigma d)^{2}}{n}}{n(n-1)}}}=\frac{6}{\sqrt{\frac{822-\frac{(120)^{2}}{20(20-1)}}{20(20-1)}}}=\frac{6}{\sqrt{\frac{822-\frac{14400}{20}}{380}}}=\frac{6}{\sqrt{\frac{822-720}{380}}} \\
& t=\frac{6}{\sqrt{\frac{102}{380}}}=\frac{6}{\sqrt{0,268}}=\frac{6}{0,518}=11,583
\end{aligned}
$$

Jadi diperoleh $\mathrm{t}_{\text {hitung }}=$ 


\section{Langkah 5. Menentukan Kaidah Pengujian}

Untuk derajat kebebasan $(\mathrm{db})=\mathrm{N}-1$

$$
20-1=19
$$

Taraf signifikansinya $\alpha=0,05$

Maka $t_{\text {tabel }}=1,729$

Jika $t_{\text {hitung }}>\mathrm{t}_{\text {tabel }}$ atau $\mathrm{t}_{\text {hitung }}<\mathrm{t}_{\text {tabel}}$, maka terdapat perbedaan yang signifikan (Ho ditolak dan $\mathrm{Ha}$ diterima)

\section{Langkah 6. Membandingkan $t_{\text {tabel }}$ dengan $t_{\text {hitung }}$}

$\begin{array}{ll}\text { Ternyata } & : t_{\text {hitung }}>\mathrm{t}_{\text {tabel }} \\ \text { Atau } & : 11,583>1,729\end{array}$

Maka : Ho ditolak dan Ha diterima

\section{Langkah 7. Simpulan}

Ho : Bahan ajar cerpen sejarah untuk meningkatkan kebahasaan siswa yang mandasar pada kearifan lokal. DITOLAK

Ha : Bahan ajar cerpen sejarah berbasis kearifan lokal untuk peningkatan kebahasaan siswa. DITERIMA.

\section{PEMBAHASAN}

Kurikulum 2013 memuat standar kompetensi yang dirancang khusus untuk mengantisipasi perubahan kebutuhan, keterampilan, dan sikap agar peserta didik menghadapi tantangan pada perubahan zaman menurut (Devi, 2018). Proses dalam penelitian dan pengembangan ini dilakukan dengan mengetahui potensi dan masalah yang ada dalam objek penelitian. Selanjutnya, peneliti mengumpulkan barbagai macam data yang sudah didapatkan dan dipilah. Data yang terkumpul akan dikelompokkan sesuai dengan jenis data masingmasing. Setelah itu peneliti membuat desain produk sesuai dengan kebutuhan potensi dan masalah yang sudah diketahui dan melakukan beberapa validasi melalui validasi ahli media, ahli materi, dan validasi guru pengampu mata pelajaran bahasa Indonesia. Setelah melakukan validasi kepada para validator, peneliti melanjutkan dengan uji coba produk kepada responden dan beberapa revisi produk yang diujicobakan untuk menghasilkan produk yang layak bagi responden. Pada tahap terakhir, produk akan diterbitkan secara masal dan bisa digunakan oleh responden.

Penelitian dan pengembangan bahan ajar modul bahasa Indonesia diawali dengan mengidentifikasi masalah dan potensi yang ada, mengumpulkan berbagai informasi mengenai situasi dan kondisi yang ada di MAN 7 Jombang. Infromasi dan data-data yang telah didapatkan kemudian dianalisis, sehingga hasil dari analisis tersebut menunjukkan bahwa pengembangan bahan ajar berupa modul layak digunakan dalam kegiatan pembelajaran. Hasil analisis data kemudian disusun dan dirancang menjadi produk pengembangan bahan ajar berupa modul. Selama masa pembuatan produk pengembangan bahan ajar modul dilakukan beberapa revisi oleh berbagai validator. Selain itu, dilakukan uji coba tes tulis berupa pretest dan posttes untuk mengetahui kelayakan produk pengembangan bahan ajar berupa modul.

Dari paparan hasil analisis data yang ada di Tabel 1, didapatkan hasil uji coba pretest dan posttest dari 20 orang responden. Hasil tersebut menunjukkan bahwa $t_{\text {hitung }}>t_{\text {tabel }}$, hasil analisis juga diperkuat dengan menggunakan analisis t-test yang menggunakan dependent sample test menunjukkan bahwa $\mathrm{t}_{\text {hitung }}=11,583$. Hasil perolehan $\mathrm{t}_{\text {hitung }}$ dilanjutkan pada uji hipotesis dengan taraf signifikan 0,05 adalah 1,729, maka $\mathrm{Ho}$ ditolak dan $\mathrm{Ha}$ diterima. 
Artinya, bahan ajar berupa modul ini dapat meningkatkan hasil belajar siswa. Berdasarkan hasil uji t di dalam paparan hasil, menunjukkan adanya perbedaan nilai rata-rata siswa sebelum dan sesudah menggunakan bahan ajar berbentuk modul. Hal ini menunjukkan bahwa penggunaan bahan ajar berbentuk modul mampu meningkatkan hasil belajar siswa.

Hasil uji coba pretest dan posttest siswa MAN 7 Jombang mengalami perbedaan, dari nilai pretest pada Tabel 1 lebih rendah dengan rata-rata 78,75, sedangkan, hasil dari nilai posttest lebih tinggi dengan rata-rata 84,65 . Jadi, terdapat perbedaan yang signifikan terhadap penggunan bahan ajar modul yang telah dikembangkan. Bahan ajar modul dapat dinyatakan mampu meningkatkan hasil belajar dan pemahaman siswa secara efektif.

\section{SIMPULAN}

Peningkatan kompetensi kebahasaan dalam menulis teks cerpen sejarah siswa MAN 7 Jombang mengalami peningkatan dari rata-rata 78,75. Sedangkan, hasil dari nilai posttest yang didapatkan oleh peserta didik lebih apik yaitu rata-rata 84,65, sehingga, terbukti lebih apik dan lebih berprestasi ketimbang prestasi peserta didik yang saat proses belajar mengajar tidak memakai bahan ajar modul.

\section{DAFTAR PUSTAKA}

Achmad, S. (2012). Strategi Kesopanan Berbahasa Masyarakat Bugis Pinrang Provinsi Sulawesi Selatan. Bahasa dan Seni: Jurnal Bahasa, Sastra, Seni, dan Pengajarannya, 40(1), 1-13.

Amalia, A., \& Doyin, M. (2015). Pengembangan Buku Panduan Menyusun Teks Cerpen dengan Menggunakan Teknik Urai Unsur Intrinsik Bagi Siswa Kelas VII Sekolah Menengah Pertama (SMP). Jurnal Pendidikan Bahasa dan Sastra Indonesia, 4(2), 16.

Borg, W. R., \& Gall, M. (1989). Education Research: An Introduction (4th Edition). New York: Longman Publisher.

Devi, P. C. (2018). Pengembangan Bahan Ajar Menulis Teks Prosedur Kompleks dengan Model Pembelajaran Discovery Learning Menggunakan Media Audio Visual (Video) di Kelas XI SMA Negeri 1 Samarinda. Diglosia: Jurnal Kajian Bahasa, Sastra, Dan Pengajarannya, 1(2), 101-114.

Fachrudin, M. U. (2016). Pengembangan Modul Sejarah M. Nitisemito dalam Pembelajaran Sejarah Pergerakan Nasional Indonesia di SMA Negeri 1 Bae Kudus Tahun Ajaran 2016/2017. (Doctoral Disertation not Publish), Universitas Negeri Semarang, Semarang.

Freire, P. (2008). Kearifan Budaya. Jakarta: Kencana Prenada Media Group.

Haryonik, Y., \& Bhakti, Y. B. (2018). Pengembangan Bahan Ajar Lembar Kerja Siswa dengan Pendekatan Matematika Realistik. MaPan: Jurnal Matematika dan Pembelajaran, 6(1), 40-55.

Komalasari, D. (2019). Kefektifan Model Problem Based Instruction (PBI) dan Model Sinektik dalam Pembelajaran Menulis Cerpen Siswa Sekolah Menengah Pertama $\mathrm{Al}$ $T A^{\prime} D I B, 12(1), 52-68$.

Listini, L., \& Saraswati, S. (2017). Meningkatkan Kemampuan Menulis Cerpen Melalui Model Pembelajaran Sinektik Siswa Kelas VII SMP Sandika Sukajadi Jurnal Bindo Sastra, 1(1), 24-27.

Maiza, R. A., Abdurahman, A., \& Zulfikarni, Z. (2018). Kontribusi Minat Baca Prosa Fiksi terhadap Keterampilan Menulis Teks Cerpen Siswa Kelas XI SMA Sungai Geringging Kabupaten Padang Pariaman Pendidikan Bahasa dan Sastra Indonesia, 7(3), 295-301. 
Mastini, M., Suwandi, S., \& Sumarwati, S. (2016). Peningkatan Keterampilan Menulis Cerpen Melalui Metode Pembelajaran Berbasis Pengalaman dan Media Audiovisual pada Sekolah Menegah Pertama Jurnal S2 Pendidikan Bahasa Indonesia, 1(1), 22-34.

Ranem, R., Mulawarman, W. G., \& Sulistyowati, E. D. (2018). Pengembangan Bahan Ajar Materi Debat dengan Metode Role Playing pada Siswa Kelas X Sekolah Menengah Atas. Diglosia, 1(2), 65-74.

Sartini. (2016). Pengembangan Modul Pembelajaran Tematik Integratif Berbasis Sosiokultural untuk Meningkatkan Kedisiplinan dan Hasil Belajar Siswa Kelas IV SD 2 Padokan Bantul. (Tesis Tidak Diterbitkan), Universitas Negeri Yogyakarta,, Yogyakarta.

Sasmita, A., \& Fajriyah, K. (2018). Pengembangan Modul Berbasis Quantum Learning Tema Ekosistem untuk Kelas V Sekolah Dasar. Refleksi Edukatika: Jurnal Ilmiah Kependidikan, 8(2), 163-170.

Setiawati, I. (2016). Strategi Meningkatkan Kemampuan Menulis Karangan Kreatif pada Siswa Kelas 4 dan 5: Studi Multikasus di MIN Rejotangan dan SDN 1 Rejotangan Tulungagung. Jurnal Dinamika Penelitian: Media Komunikasi Penelitian Sosial Keagamaan, 16(1), 107-127.

Sukistiono. (2017). Pengembangan Bahan Ajar Menulis Teks Cerpen Menggunakan Pendekatan Berbasis Teks dengan Metode Cerpen-Gram untuk Siswa SMP/Mts. Kelas IX. (Tesis Tidak Diterbitkan ), Universitas Lampung, Bandar Lampung.

Wahjudi, E. (2016). Pengembangan Media Pembelajaran Modul Interaktif pada Materi Jurnal Khusus Kelas X Akuntansi di SMK Negeri Mojoagung (pp. 1-7).

Wardarita, R. (2010). Kiat Menulis Cerita Pendek. Bandung: Angkasa. 